\title{
Penerapan Gaya Kepemimpinan Transformasional Dalam Manajemen PAUD di Kecamatan Sidorejo Salatiga
}

\author{
Mei Hardika Senny, Lanny Wijayaningsih, Mozes Kurniawan \\ 272014003@student.uksw.edu, lanny.wijayaningsih@yahoo.com, \\ mozes.kurniawan@staff.uksw.edu \\ PG-PAUD, FKIP, Universitas Kristen Satya Wacana
}

\author{
The Application of Transformational Leadership in Early Childhood Education Management \\ in Sidorejo Salatiga Sub District
}

\begin{abstract}
The purpose of this study is to prove that the transformational leadership style can be applied and to describe how it is applied in Early Childhood Education management in Sidorejo District of Salatiga. This descriptive qualitative research used the sampling using technique purposive. Techniques of collecting data using interviews, observation and documentation. Many phenomena researchers find in some kindergartens in the city of Salatiga are examples: many teachers resigned each year, they lack of motivation and awareness of their duties as teachers or perform tasks only because of rewards or punishment, and lack of trust and loyalty to the institution school. With the implementation of this transformational leadership style, it provides some positive impacts, principals being role models, encouraging subordinate performance, harmonizing the work environment, empowering employees, acting on the value system, continuously improving their capabilities, and having the ability to cope with complex situations. So with this study, the authors hope this transformational leadership style can be applied in school institutions that have not used this style of leadership, especially early childhood institutions because the results show that the transformational leadership style is very effective applied to early childhood education management.
\end{abstract}

Keywords: early childhood, leadership style, transformational

Received date: 15 Maret 2018

Article Info

Revised date: 10 April 2018

Accepted date: 4 Mei 2018

\section{PENDAHULUAN}

Pemimpin adalah orang yang mampu memimbing, mempergunakan wewenangnya dan mengarahkan kelompoknya untuk melaksanakan tugas guna mencapai tujuan. Sedangkan kepemimpinan ialah usaha seorang pemimpin untuk mengkoordinasikan, memberi motivasi dan mempengaruhi tingkah laku kelompoknya untuk mencapai suatu tujuan. Suatu lembaga dapat dikatakan sukses apabila kualitas kepemimpinan tersebut dapat membuat tujuan dari sebuah lembaga tersebut bisa tercapai. Penentu maju mundurnya dan hidup matinya suatu lembaga tergantung pada cara yang diaplikasikan oleh seorang pemimpin di lembaga tersebut (Asmani, 2012: 9-10). Kepemimpinan berkaitan dengan seni dan kemampuan mempengaruhi seseorang atau sekelompok orang untuk bertindak. Sedangkan manajemen merupakan seni dan ilmu untuk mengatur agar orang mau bertindak (Danim dan Suparno 2009). Menurut Wikipedia kata manajemen berasal dari bahasa Prancis kuno management yang artinya seni melaksanakan dan mengatur. Baik manajemen maupun kepemimpinan, keduanya mendorong orang untuk bertindak. Manajemen mengedepankan pada seni yang memungkinkan orang bertindak, sedangkan kepemimpinan mengedepankan pada pengaruh yang memotivasi orang untuk bertindak.

Gaya kepemimpinan adalah perilaku dan strategi, sebagai hasil kombinasi dari falsafah, keterampilan, sifat, sikap, yang sering diterapkan seorang pemimpin ketika 
mencoba memengaruhi kinerja bawahannya.Menurut Rivai (2014: 42), gaya kepemimpinan adalah sekumpulan ciri yang digunakan pimpinan untuk memengaruhi bawahan agar sasaran organisasi tercapai atau dapat pula dikatakan bahwa gaya kepemimpinan adalah pola perilaku dan strategi yang disukai dan sering diterapkan oleh seorang pemimpin. Ada dua macam gaya kepemimpinan menurut Ratnaningsih (2009: 126), yaitu gaya kepemimpinan transaksional dan gaya kepemimpinan transformasional. Gaya kepemimpinan transaksional adalah gaya kepemimpinan yang di dalamnya menggunakan imbalan ataupun hukuman untuk memotivasi dan mengukur prestasi kerja anggotanya. Sedangkan gaya kepemimpinan transformasional adalah gaya kepemimpinan yang di dalamnya terdapat motivasi dari pemimpin kepada anggotanya. Gaya kepemimpinan yang ideal adalah gaya kepemimpinan yang memiliki penekanan dalam hal pernyataan visi dan misi yang jelas, penggunaan komunikasi secara efektif, pemberian rangsangan secara intelektual, serta perhatian pribadi terhadap permasalahan individu anggotanya. Semua hal tersebut terdapat pada gaya kepemimpinan trnasformasional. Gaya kepemimpinan transformasional perlu diterapkan karena pada masa kini terdapat berbagai informasi yang seyogyanya dapat ditransformasikan kepada guru, tenaga administrasi, siswa dan orang tua.

Sampai sekarang, kepemimpinan masih menjadi pembahasan yang menarik untuk dikaji dan diteliti, namun masih sedikit yang memahami. Adapun permasalahan yang penulis temukan di beberapa lembaga PAUD di kota Salatiga yaitu, kurangnya komunikasi dan kepercayaan antara pemimpin dan guru yang bekerja di sekolah tersebut, kurang memahami bahwa setiap individu memiliki kebutuhan, keinginan, dan keahlian yang berbeda-beda, dan kurangnya kerja sama dikarenakan adanya perasaan bahwa pemimpin memiliki hak untuk memberi perintah bawahannya. Beberapa lembaga PAUD di kota Salatiga masih menggunakan gaya kepemimpinan transaksional. Hal ini dibuktikan dengan pengamatan peneliti pada saat observasi yaitu pemimpin memiliki sifat yang keras hati (saklek) dalam pemberian tugas, hal ini menyebabkan bawahan tidak dapat berkreasi dan mengembangkan potensi yang ada dalam dirinya tersebut. Permasalahan tersebut menyebabkan menurunnya rasa kagum, hormat, loyalitas serta kinerja pada guru. Seperti contoh, banyak guru yang mengundurkan diri setiap tahunnya, mereka bekerja atas didasarkan perjanjian bukan dengan hati, oleh karena itu hasilnya pun kurang maksimal dikarenakan melakukan tugas apa adanya. Dengan adanya fenomena yang ada di lembaga sekolah, penulis ingin melalui penelitian ini, pengelola maupun pemimpin PAUD dapat melakukan pembaharuan terhadap gaya kepemimpinan yang sudah berjalan dalam manajemen PAUD berpindah ke dalam gaya kepemimpinan transformasional. Jung dan Avolio (sebagaimana dikutip Sunarsih 2001, 200:209) juga menyatakan bahwa kepemimpinan transformasional bukan hanya sekedar sebuah perjanjian tetapi lebih didasarkan kepada kepercayaan dan komitmen, namun di dalamnya juga meliputi pengembangan hubungan yang lebih dekat antara pemimpin dengan pengikutnya. Prinsip dari kepemimpinan transformasional adalah memotivasi bawahan agar berbuat lebih baik dari apa yang biasa dilakukan dengan tujuan meningkatkan kepercayaan dan keyakinan diri yang berpengaruh pada peningkatan kerja.

Nowack (2004, 311:313) meneliti pengaruh efektivitas kepemimpinan terhadap kesehatan psikologi karyawan, termasuk kepuasan kerja, motivasi, stres, retensi dan kinerja karyawan. Hasilnya menyimpulkan bahwa, karyawan berpikir pemimpin yang memiliki kepemimpinan buruk menyebabkan karyawan cenderung untuk keluar dari organisasi, motivasi kerja rendah, lingkar kerja tidak sehat, stres yang lebih tinggi. Hasil penelitian ini mendukung hipotesis bahwa kepemimpinan memberikan pengaruh yang signifikan untuk menciptakan motivasi bekerja, termasuk kepuasan kerja, stres dan suasana kerja.Selain hal tersebut, kepemimpinan dapat menciptakan inspirasi untuk memiliki rasa kekaguman, kebanggaan dan kesetiaan kepada karyawan sehingga tercipta motivasi untuk melakukan tugas lebih dari yang diharapkan. 
Berdasarkan paparan latar belakang tersebut di atas, maka penulis merumuskan masalah penelitian sebagai berikut: Bagaimana penerapan gaya kepemimpinan transformasional dalam manajemen PAUD di Kecamatan Sidorejo? Tujuan penelitian ini adalah untuk mengetahui penerapam gaya kepemimpinan transformasional dalam manajemen PAUD di kecamatan Sidorejo. Dari tujuan yang telah dirumuskan, maka hasil penelitian ini diharapkan mampu memberikan sumbangan pada dunia pendidikan dan dapat bermanfaat pada masyarakat luas, khususnya pada bidang pendidikan.

Hasil dari penelitian ini diharapkan mampu memberikan contoh gaya kepemimpinan transformasional untuk diterapkan dalam pelaksanaan manajemen dalam lembaga PAUD, sehingga dapat meningkatkan mutu sumber daya manusia yang ada, memberi masukan kepada kepala sekolah PAUD di kecamatan Sidorejo kota Salatiga.

\section{KAJIAN PUSTAKA}

Pemimpin adalah seseorang yang sangat berpengaruh dan memainkan peranan penting terhadap aktivitas anggotanya dalam merumuskan sesuatu guna mencapai tujuan (Kartini Kartono, 2003: 27). Cara mempengaruhi dan memotivasi seseorang agar orang tersebut mau berkontribusi untuk keberhasilan organisasi, itulah kepemimpinan (House, sebagaimana dikutip Gary Yukl, 2009: 4). Kepemimpinan dibutuhkan manusia karena adanya keterbatasan-keterbatasan pada diri manusia yang menimbulkan kebutuhan untuk memimpin dan dipimpin. Oleh beberapa ahli, pemimpin dipandang sebagai inti dari manajemen dan perilaku kepemimpinan merupakan inti perilaku manajemen. Inti kepemimpinan adalah pembuatan keputusan, termasuk keputusan untuk tidak memutuskan. Kepemimpinan dan manajemen akan berjalan jika ada keputusan yang dijalankan. Seorang pemimpin yang memiliki sifat-sifat kepemimpinan dapat membuat sebuah manajemen mencapai tujuan (Danim dan Suparno, 2009: 6).

Gaya Kepemimpinan diartikan sebagai perilaku atau cara yang dipilih dan dipergunakan pemimpin dalam mempengaruhi pikiran, perasaan, sikap dan perilaku para anggota organisasi atau bawahannya (Thoha, 2013: 49). Sedangkan tipe kepemimpinan dapat diartikan sebagai bentuk pola atau jenis kepemimpinan, yang di dalamnya diimplementasikan beberapa perilaku atau gaya kepemimpinan sebagai pendukungnya. Penulis memilih menggunakan gaya kepemimpinan dikarenakan di dalamnya langsung terdapat perilaku yang digunakan seorang pemimpin untuk mempengaruhi bawahannya.

\section{Gaya-Gaya Kepemimpinan}

Menurut Ratnaningsih (2009: 126) gaya kepemimpinan merupakan norma perilaku yang digunakan oleh seorang pemimpin untuk mempengaruhi perilaku orang lain seperti yang ia inginkan. Burn (1978 seperti yang dikutip oleh Ratnaningsh 2009: 126) menyatakan bahwa gaya kepemimpinan dapat dikelompokkan ke dalam dua tipe yang berbeda yaitu gaya kepempinan transformasional dan gaya kepemimpinan transaksional. Kedua gaya kepemimpinan tersebut merupakan dua hal yang berbeda (saling bertentangan) namun sangat penting dan dibutuhkan setiap organisasi.

Kepemimpinan transformasional harus menjadi basis kepala sekolah dalam melakukan transformasi tugas kesehariannya dikarenakan hasil dari penelitian beberapa ahli ditemukan bahwa dalam esensi kepemimpinan transformasional terdapat kultur sekolah yang positif melalui motivasi dan prestasi siswa yang tinggi, meningkatkan kolaborasi antar guru, dan mengubah sikap guru terhadap pekerjaannya ke depan menjadi positif. Hal ini akan mendorong sekolah menjadi tempat dimana guru-guru memiliki rasa positif terhadap pekerjaan dan siswa termotivasi untuk belajar (Danim dan Suparno, 2009: 46-47). 
Penerapan Gaya Kepemimpinan Transformasional Dalam Manajemen PAUD di Kecamatan Sidorejo Salatiga (Mei Hardika Senny, Lanny Wijayaningsih, Mozes Kurniawan)

\section{Gaya Kepemimpinan Transformasional}

Burn (yang dikutip dalam Yukl, 2010: 290) mendeskripsikan bahwa kepemimpinan transformasional adalah merupakan sebuah proses saat pemimpin dan bawahan mengembangkan satu sama lain tingkat moralitas dan motivasi yang tinggi. Pada umumnya kepemimpinan transformasional mempunyai beberapa dampak positif terhadap kinerja karyawan. Hal itu dikarenakan pemimpin dengan gaya transformasional mengubah dan memotivasi anggotanya dengan: (1) membuat anggotanya lebih sadar akan pentingnya hasilhasil suatu pekerjaan, (2) mendorong anggotanya untuk mengedepankan kepentingan organisasi atau tim daripada kepentingan diri sendiri, dan (3) mengaktifkan kebutuhankebutuhan anggotanya pada yang lebih tinggi (Yukl, 2009: 305).

Ada empat unsur yang mendasari kepemimpinan transformasional yaitu sebagai berikut: (1) Idealized Influence - Charisma, yaitu memberi wawasan serta kesadaran akan misi, membangkitkan kebanggaan, serta menumbuhkan sikap hormat dan kepercayaan pada para bawahannya. (2) Inspirational Motivation, yaitu menumbuhkan ekspektasi yang tinggi melalui pemanfaatan simbol-simbol untuk memfokuskan usaha dan mengkomunikasikan tujuan-tujuan penting dengan cara yang sederhana. (3) Intellectual Stimulation, yaitu meningkatkan intelegensia, rasionalitas, dan pemecahan masalah secara seksama. (4) Individualized Consideration, yaitu memberikan perhatian, membina, membimbing, dan melatih setiap orang secara khusus dan pribadi (Pidekso dan Harsiwi, 2001: 3).

Menurut Burn (sebagaimana dikutip Wirawan, 2008: 2) kepemimpinan transformasional mempunyai ciri-ciri sebagai berikut: (a) pemimpin dan anggota memiliki tujuan sama yang didalamnya menggambarkan nilai-nilai, motivasi, keinginan, kebutuhan, aspirasi, dan harapan mereka. Pemimpin bertindak atas namanya sendiri dan atas nama para anggotanya.; (b) Motivasi dan potensi antara pemimpin dan anggota untuk mencapai tujuan tersebut berbeda meskipun mereka memiliki tujuan yang sama.; (c) Mengemukakan visi yang menghubungkan dan menyatukan anggota dan pemimpinnya dengan mendorong berkembangnya masyarakat baru terdapat dalam kepemimpinan transformasional yang merupakan kepemimpinan moral untuk meningkatkan perilaku manusia. Dalam kepemimpinan transformasional, antara anggota dan pemimpinnya saling menciptakan moral yang makin lama makin meninggi.; (d) dengan adanya kepemimpinan transformasional, mengajarkan para anggota bagaimana menjadi pemimpin yang melaksanakan nilai-nilai akhir yang meliputi kebebasan, kemerdekaan, persamaan dalam masyarakat dengan melaksanakan peran aktif dalam perusahaan.

Berikut adalah beberapa indikator gaya kepemimpinan transformasional menurut Robbins (2010: 263):

1. Kharisma: Pemimpin kharismatik adalah pemimpin yang mewujudkan atmosfir motivasi atas dasar komitmen dan identitas emosional pada visi, filosofi, dan gaya mereka dalam diri bawahannya. Kharisma merupakan kombinasi dari pesona dan daya tarik pribadi yang ikut berperan untuk membuat orang lain mendukung visi.

2. Motivasi Inspiratif: Motivasi inspiratif disini yang dimaksud adalah pemimpin yang bergairah dalam mengkomunikasikan masa depan organisasi yang idealis untuk menumbuhkan semangat timnya, tidak hanya semangat individu. Motivasi yang diberikan pemimpin kepada anggotanya disini adalah pentingnya visi dan misi yang sama. Karena dengan adanya visi yang sama menjadikan anggota untuk bekerja sama mencapai tujuan jangka panjang dengan optimis.

3. Stimulasi Intelektual: Stimulasi intelektual yaitu pemimpin yang mampu membentuk karyawan dalam memecahkan masalah lama dengan inovasi yang dimilikinya. Pemimpin berusaha mendorong perhatian dan kesadaran anggota akan permasalahan yang dihadapi dengan pendekatan-pendekatan atau perspektif yang baru. 
4. Perhatian yang Individual: Perhatian yang individual disini adalah pimpinan selalu memperhatikan dan memperlakukan karyawannya secara individual, serta melatih dan menasehati. Pemimpin mengajak anggota untuk menyadari kemampuan orang lain dan mengembangkan potensi yang ada dalam diri anggota masing-masing.

Ada tujuh prinsip untuk menciptakan kepemimpinan transformasional yang sinergis menurut (Rees: 2001) yaitu :

a. Simplifikasi

Kemampuan serta keterampilan dari seorang pemimpin dalam mengungkapkan visi secara jelas dan praktis menjadi hal pertama yang penting untuk diimplementasikan.

b. Motivasi

Kemampuan untuk mendapatkan komitmen dari setiap orang yang terlibat terhadap visi yang sudah dijelaskan adalah hal kedua yang

perlu dilakukan oleh seorang pemimpin.

c. Fasilitasi

Mampu secara efektif memfasilitasi "pembelajaran" yang terjadi di dalam organisasi secara kelembagaan, kelompok, ataupun individual. Hal tersebut akan berdampak pada semakin bertambahnya modal intelektual dari setiap orang yang terlibat di dalamnya.

d. Inovasi

Kemampuan untuk secara berani dan bertanggung jawab melakukan suatu perubahan apabila diperlukan dan menjadi suatu tuntutan dengan perubahan yang terjadi. Pemimpin transformasional harus sigap merespon perubahan tanpa mengorbankan rasa percaya dan tim kerja yang sudah dibangun. Dalam suatu organisasi yang efektif dan efisien, setiap orang yang terlibat perlu mengantisipasi perubahan dan tidak takut akan perubahan tersebut.

e. Mobilitas

Pengerahan semua sumber daya yang ada untuk melengkapi dan memperkuat pengikutnya yang penuh dengan tanggung jawab, dalam mencapai visi dan tujuan.

f. Siap Siaga

Kemampuan untuk selalu siap belajar tentang diri mereka sendiri dan menyambut perubahan dengan paradigma baru yang positif.

g. Tekad

Tekad bulat untuk selalu sampai pada akhir dan menyelesaikan sesuatu dengan baik dan tuntas. Untuk itu, diperlukan dukungan dari pengikut berupa pengembangan disiplin spiritualitas, emosi, dan fisik serta komitmen.

Karakteristik pemimpin transformasional menurut Bass (dalam Yulk, 2010: 316) adalah: (a) Menciptakan visi dan kekuatan misi, (b) Menanamkan kebanggaan pada diri bawahan, (c) Memperoleh dan memberikan penghormatan, (d) Menumbuhkan kepercayaan di antara bawahan, (e) Mengkomunikasikan harapan tertinggi, (f) Menggunakan simbol untuk menekankan usaha tinggi, (g) Mengeskpresikan tujuan penting dalam cara yang sederhana (h) Menumbuhkan dan meningkatkan kecerdasan, rasionalitas dan pemecahan masalah secara hati-hati pada bawahan, (i) Memberikan perhatian secara personal, (j) Membimbing dan melayani tiap bawahan secara indivdual, (k) Melatih dan memberikan saran-saran, (l) Menggunakan dialog dan diskusi untuk mengembangkan potensi dan kinerja bawahan. 
Penerapan Gaya Kepemimpinan Transformasional Dalam Manajemen PAUD di Kecamatan Sidorejo Salatiga (Mei Hardika Senny, Lanny Wijayaningsih, Mozes Kurniawan)

\section{Gaya Kepemimpinan Transaksional}

Bass (2003: 56) menyatakan bahwa kepemimpinan transaksional adalah kepemimpinan yang di dalamnya terdapat suatu proses pertukaran yang menyebabkan anggota mendapat imbalan dan membantu anggotanya mengidentifikasikan apa yang harus dilakukan guna mencapai tujuan yang diharapkan seperti kualitas pengeluaran yang baik, penjualan atau pelayanan yang lebih dari karyawan, serta mengurangi biaya produksi. Damarsari, seperti yang dikutip oleh Yoga (2006: 33) menyatakan bahwa kepemimpinan transaksional yaitu hubungan antara pemimpin dengan bawahan yang berlandaskan pada adanya pertukaran (exchange process) atau adanya tawar menawar antara pimpinan dan bawahannya. Disebutkan juga tiga unsur utama dalam kepemimpinan transaksional menurut Ratnaningsih (2009: 125) yaitu sebagai berikut: (1) Imbalan Kontingensi (Contingent Reward). Yaitu pemberian imbalan sesuai dengan pekerjaan yang telah dilakukan bawahan sesuai dengan kesepakatan, biasanya disebut juga sebagai bentuk pertukaran yang aktif. Artinya bawahan akan mendapatkan imbalan atas tujuan yang dapat dicapainya dan tujuan tersebut telah disepakati bersama antara pemimpin dan bawahan. (2) Manajemen Eksepsi (Management by Exception).Yaitu merupakan transaksi yang aktif dan pasif. Aktif yaitu pemimpin secara terus menerus melakukan pengawasan terhadap bawahannya untuk mengantisipasi adanya kesalahan. Sedangkan pasif berarti intervensi dan kritik dilakukan setelah kesalahan terjadi, pemimpin akan menunggu semua proses dalam tugas selesai, selanjutnya menentukan ada atau tidaknya kesalahan. (3) Laissez - Faire. Yaitu kepemimpinan gaya kebebasan atau gaya liberal, memberi kebebasan luas terhadap kelompok yang secara esensial terlihat sebagai kelompok yang tidak mempunyai kepemimpinan. Dalam kelompok yang diteliti, tipe kepemimpinan seperti ini menghasilkan tindakkan agresif paling besar dalam kelompok.

Untuk memotivasi agar bawahan melakukan tanggung jawab mereka, para pemimpin transaksional sangat mengandalkan pada sistem pemberian penghargaan dan hukuman kepada bawahannya (Daryanto, 2005: 8). Pemimpin transaksional melebihi dari fungsi manajemen, dimana: (1) Pemimpin transaksional adalah pekerja keras, toleran dan adil, (2) Pemimpin transaksional bangga dalam mempertahankan segala sesuatu berjalan dengan lancar dan efisien, (3) Pemimpin transaksional seringkali menitikberatkan aspek impersonal dari kinerja, seperti rencana, jadwal, dan anggaran, (4) Pemimpin transaksional memiliki kepekaan akan komitmen pada organisasi serta menyesuaikan diri dengan norma dan nilai yang berlaku dalam organisasinya (Kartono, 2005: 24).

Kepemimpinan transaksional memiliki banyak potensi-potensi yang mendukung kinerja organisasi, tetapi masih banyak hal yang perlu dicermati, bahwa ada beberapa hal yang harus dilihat dalam kepemimpinan transaksional yaitu melihat dari dimensi kepemimpinan transformasional.

Tabel 2.2.

Kepemimpinan Transformasional VS Transaksional

\begin{tabular}{|c|c|}
\hline Transformasional & Transaksional \\
\hline 1. Atribut-atribut pengaruh ideal & 1. Kontingensi ganjaran (contingence rewards) \\
\hline 2. Perilaku pengaruh ideal & 2. Manajemen dengan pengecualian aktif (active management by \\
\hline 3. Motivasi inspirasional & axception) \\
\hline 4. Stimulasi intelektual & 3. Manajemen dengan pengecualian pasif (pasive management \\
\hline 5. Individualisasi konsiderasi. & by axception) \\
\hline
\end{tabular}


Dari beberapa paparan tersebut di atas, dinyatakan bahwa gaya kepemimpinan transaksional dan transformasional dapat saling berdampingan. Hasil studi terhadap delapan proyek penelitian di beberapa negara menunjukkan bahwa praktek transaksional membantu mereka dalam manajemen rutin, sedangkan praktek transformasional membantu mereka dalam mengupayakan perubahan. Meskipun berseberangan, bukan berarti gaya kepemimpinan transaksional tidak baik. Gaya kepemimpinan transaksional juga baik, akan tetapi gaya kepemimpinan transformasional masih lebih baik.

\section{Kepala Sekolah}

Kepala sekolah memiliki arti sebagai orang yang memimpin suatu lembaga, tempat berlangsungnya kegiatan pembelajaran. Wahjosumidjo mengemukakan: "Kepala sekolah adalah seorang tenaga fungsional guru yang diberi tugas untuk memimpin suatu sekolah dimana diselenggarakan proses belajar mengajar atau tempat dimana terjadi interaksi antara guru yang memberi pelajaran dan murid yang menerima pelajaran". Sedangkan menurut Permendikbud Nomor: 0296/U/1996 tentang Penugasan Guru Pegawai Negeri Sipil sebagai Kepala Sekolah di lingkungan Depdikbud, disebutkan bahwa kepala sekolah adalah seorang guru yang mendapatkan tugas tambahan untuk memimpin penyelenggaraan pendidikan dan upaya peningkatan mutu pendidikan sekolah. Kepala sekolah dianggap menjadi figur terpenting dalam penyelenggaraan pendidikan dan dituntut dapat melaksanakan berbagai peran untuk mencapai tujuan sekolah. Dalam melaksanakan tugasnya, seorang kepala sekolah memiliki tugas pokok dan fungsi peran yang tinggi. Peran kepala sekolah yang mengacu pada ketetapan Mendiknas dikemukakan oleh Mulyasa (2009: 98-122) sebagai sebuah paradigma baru yang disingkat EMASLIM yaitu, kepala sekolah sebagai educator, manager, supervisor, leader, inovator dan motivator.

\section{Kelebihan dan Kekurangan Gaya Kepemimpinan}

Dengan penerapan gaya kepemimpinan transformasional, maka anggota akan melakukan tugasnya dengan maksimal dikarenakan pemberian tugas dari pemimpin bukanlah suatu beban yang berat. Hal tersebut disebabkan pemimpin dapat mempengaruhi anggotanya sehingga ketika diberikan tugas, anggota akan menerima dengan senang hati. Dalam gaya kepemimpinan transformasional tersebut pemimpin tidak hanya menggunakan kekuasaan dan kekuatannya untuk meraih cita-cita (Oshagbeni seperti yang dikutip dalam Rahyuda 2008: 19). Selain itu Luthans (2006: 653), juga menerangkan beberapa kelebihan yang terdapat dalam gaya kepemimpinan transformasional antara lain : a) Memiliki pemahaman bahwa dirinya adalah alat perubahan, b) Memiliki keberanian, c) Memiliki kepercayaan terhadap orang lain, d) Sebagai motor penggerak nilai-nilai positif, e) Memiliki kemampuan belajar tanpa mengenal waktu, f) Memiliki kemampuan ketika menemukan permasalahan yang kompleks, ambigu dan tidak ada kepastian, g) Memiliki visi dan misi yang jelas.

Sebaliknya, sedangkan dengan adanya gaya kepemimpinan transaksional maka akan membuat anggota melakukan pekerjaannya hanya karena agar mendapatkan upah. Hal tersebut menyebabkan komitmen anggota pada lembaganya tidak akan berlangsung lama. Tugas yang dilaksanakan anggota hanya sebatas pada negosiasi dan mengenyampingkan solusi dan tujuan bersama (Avolio, Bass dan Jung sebagaimana dikutip oleh Hariza 2017: 34)

\section{METODE PENELITIAN}

Metode yang digunakan penulis adalah menggunakan jenis pendekatan kualitatif, yaitu perolehan data melalui wawancara, observasi, dan dokumentasi. Menurut Sugiyono (2010:15), metode penelitian kualitatif adalah metode penelitian yang berlandaskan pada filsafat postpositivisme, digunakan untuk meneliti pada kondisi obyek yang alamiah, peneliti adalah sebagai instrumen kunci, pengambilan sampel sumber data dilakukan secara purposive 
Penerapan Gaya Kepemimpinan Transformasional Dalam Manajemen PAUD di Kecamatan Sidorejo Salatiga (Mei Hardika Senny, Lanny Wijayaningsih, Mozes Kurniawan)

dan snowbaal, teknik pengumpulan dengan trianggulasi, analisis data bersifat induktif, dan hasil penelitian lebih menekankan makna dari pada generalisasi. Penelitian ini bertujuan untukmemberikan gambaran secara mendetail tentang penerapan gaya kepemimpinan transformasional untuk mengelola sebuah lembaga PAUD.

Jenis penelitian yang dipakai oleh peneliti adalah jenis deskriptif kualitatif. Deksriptif kualitatif adalah jenis penelitian yang mempelajari tentang masalah-masalah yang ada di sekitar dan tata cara yang berlaku. Di dalam penelitian ini terdapat upaya mendiskripsikan, mencatat, menganalisis dan menginterpretasikan kondisi yang saat ini terjadi. Sedangkan subjek penelitian ini adalah beberapa kepala sekolah dan guru-guru di beberapa lembaga PAUD di Kecamatan Sidorejo Kota Salatiga. Teknik pengambilan sampel menggunakan Random Sampling. Penelitian ini dilaksanakan pada bulan Juli sampai dengan bulan Desember.

Dalam penelitian ini peneliti menggunakan teknik pengumpulan data dengan instrumen wawancara. Adapun indikator dari gaya kepemimpinan transformasional menurut Robbins (2010: 263) adalah: kharisma, motivasi inspiratif, stimulasi intelektual, dan perhatian yang individual. Selain dari teori tersebut, pedoman wawancara yang digunakan peneliti adalah pertanyaan-pertanyaan yang diidentifikasi oleh Johnson dan Johnson dalam buku Manajemen dan Kepemimpinan Transformasional Kekepalasekolahan oleh Sudarwan Danim dan Suparno (2009).

\section{HASIL DAN PEMBAHASAN}

Dalam penelitian ini ditemukan berbagai penerapan gaya kepemimpinan kepala sekolah yang bermacam-macam di TK atau PAUD di Kecamatan Sidorejo, salah satunya adalah gaya kepemimpinan transformasional. Hasil pengambilan sampel yang dilakukan oleh peneliti menjadi bukti bahwa gaya kepemimpinan transformasional dapat diterapkan di TK atau PAUD di Kecamatan Sidorejo contohnya yaitu di KB7TK Strawberry serta di TK Eben Haezer.

Hasil penelitian dari Joa-Nan Cheng (2011) The Effect Of Kindergarten Principals' Leadership Behaviors On Teacher Work Performance mengatakan bahwa terdapat pengaruh antara perilaku kepemimpinan kepala sekolah terhadap kinerja guru. Regresi dan persamaan struktural permodelan analisis menunjukkan bahwa penggunaan kepedulian empati oleh kepala TK memiliki pengaruh positif terhadap kinerja guru, kepemimpinan berbasis emosi menunjukkan dalam bentuk kepedulian empati bisa digunakan untuk meningkatkan kinerja guru. Dalam penelitian ini 732 guru TK Taiwan yang melengkapi kuesioner tentang kinerja mereka dan bagaimana hal itu dipengaruhi oleh perilaku kepemimpinan kepala sekolah hasilnya menunjukkan bahwa penggunaan perhatian empati oleh kepala sekolah TK berpengaruh positif terhadap kinerja guru. Meskipun perintah asertif ditemukan memiliki pengaruh positif, korelasi dengan kinerja kerja lebih rendah dari pada dengan perhatian empati. Imbalan dan hukuman (yang terdapat dalam gaya kepemimpinan transaksional) tidak berpengaruh signifikan terhadap peningkatan kinerja guru. Kepemimpinan berbasis emosi dalam bentuk menunjukkan kepedulian empati dapat digunakan untuk meningkatkan kinerja guru TK. Temuan penelitian ini sedikit berbeda dengan Kusumawati (2017: 19) yang mengemukakan bahwa sarana pendidikan merupakan sarana penunjang bagi proses belajar mengajar. Slameto (2014: 4) juga mengatakan bahwa salah satu tujuan sertifikasi guru adalah untuk meningkatkan proses dan mutu hasil pendidikan. Hal ini membuktikan bahwa peningkatan mutu pendidikan selain melalui gaya kepemimpinannya dapat juga melalui manajemen sarana prasarananya.

Kepemimpinan transformasional membutuhkan dua hal pokok yaitu, pertama, adanya visi yang memungkinkan guru-guru memiliki perasaan terpanggil atau motif intrinsik sebagai pendidik. Motif intrinsik disini yang dimaksud adalah dorongan dari dalam diri seseorang. 
Apabila seseorang memiliki motif dalam melakukan sebuah pekerjaan, maka pengaruh yang dihasilkan dalam pekerjaannya akan sangat besar. Namun, apabila motifnya tidak kuat, akan membuat seseorang tidak bergairah dalam melakukan suatu pekerjaan. Jika seorang guru memiliki motif intrinsik, maka dalam mendidik muridpun hasilnya akan maksimal, karena guru tahu apa yang sudah menjadi kewajiban dan tanggung jawabnya sebagai seorang guru. Yang kedua adalah budaya sosial atau budaya organisasi, dimana kepala sekolah dan seluruh staf karyawan saling memperhatikan, saling memahami dan menghargai dan mempedulikan secara tulus. Hal ini merupakan esensi dari kepemimpinan transformsional yang dikemukakan oleh Fry (2003). Selain esensi tersebut, dalam kepemimpinan transformasional juga terdapat pembaruan. Pembaruan dalam dunia pendidikan anak usia dini sangat diperlukan. Karena, jika dalam kegiatan belajar mengajar yang diberikan kepada anak selalu monoton, maka anak akan menjadi bosan dan hasil yang diharapkan tidak tercapai. Seperti teori psikoanalisa yang dikemukakan oleh Freud yaitu, seseorang merasa senang dan puas melakukan suatu pekerjaan karena dipengaruhi oleh masa lampaunya. Jika masa kanak-kanak seseorang itu penuh dengan pengalaman yang memotivasi, maka akan mendorong orang tersebut melakukan suatu pekerjaan dengan senang hati atau tanpa paksaan.

Dalam pengamatan peneliti, gaya kepemimpinan transformaasional sangat ideal untuk diterapkan dalam sekolah-sekolah terutama lembaga PAUD dikarenakan dalam gaya kepemimpinan transformasional terdapat indikator-indikator yang sangat diperlukan untuk menjadi acuan kepala sekolah dalam membimbing para guru guna meningkatkan kemampuannya terus menerus, mengembangkan potensi yang ada dalam setiap guru, dan menjaga hubungan baik antar guru maupun semua warga sekolah. Beberapa indikator gaya kepemimpinan transformasional tersebut adalah perhatian yang individual, sikap terbuka, dan stimulasi intelektual. Seorang pemimpin yang transformasional sangat memperhatikan karyawannya secara individual baik dalam kemampuan individual masing-masing maupun perhatian emosional dan empati, sikap yang terbuka juga terdapat dalam kepemimpinan transformasional yang menjadikan karyawan lebih kreatif, dan stimulasi intelektual.

Tabel 4.1.

Penerapan Gaya Kepemimpinan Transformasional di KB Strawberry dan TK Kristen 03 Eben Haezer Salatiga

\begin{tabular}{|c|c|}
\hline Pelaksanaan & Pembahasan \\
\hline $\begin{array}{l}\text { Kepala sekolah dapat menerima } \\
\text { pembaharuan dalam dunia pendidikan }\end{array}$ & Sejalan dengan prinsip kepemimpinan transformasional yaitu Inovasi. \\
\hline $\begin{array}{l}\text { Kepala sekolah menjabarkan visi, misi } \\
\text { dan tujuan sekolah secara jelas }\end{array}$ & $\begin{array}{l}\text { Sejalan dengan prinsip kepemimpinan transformasional yaitu } \\
\text { Simplifikasi. }\end{array}$ \\
\hline $\begin{array}{l}\text { Kepala sekolah memfasilitasi bawahan } \\
\text { agar meningkatkan kemampuan } \\
\text { interpersonalnya }\end{array}$ & $\begin{array}{l}\text { Sejalan dengan prinsip kepemimpinan transformasional yaitu } \\
\text { Fasilitasi. }\end{array}$ \\
\hline $\begin{array}{l}\text { Kepala sekolah mampu membangun } \\
\text { rasa percaya dan sikap terbuka pada } \\
\text { bawahan }\end{array}$ & $\begin{array}{l}\text { Sejalan dengan karakteristik kepemimpinan transformasional menurut } \\
\text { Bass (dalam Yulk, } 2010 \text { :316). }\end{array}$ \\
\hline $\begin{array}{l}\text { Kepala sekolah memberikan motivasi } \\
\text { dan perhatian secara personal }\end{array}$ & $\begin{array}{l}\text { Sejalan dengan prinsip kepemimpinan transformasional yaitu Motivasi } \\
\text { dan Indikator Gaya Kepemimpinan Transformasional yaitu Motivasi } \\
\text { Inspiratif serta Stimulasi Intelektual. }\end{array}$ \\
\hline $\begin{array}{l}\text { Pemimpin memiliki sifat tegas, adil } \\
\text { dan pantang menyerah }\end{array}$ & $\begin{array}{l}\text { Sejalan dengan Kunci Sukses Kepemimpinan Kepala Sekolah dalam } \\
\text { buku } \quad \text { Manajemen } \quad \text { Kepemimpinan } \\
\text { Kekepalasekolahan oleh Sudarwo Danim dan Suparno. }\end{array}$ \\
\hline $\begin{array}{l}\text { Pemimpin memiliki kepedulian } \\
\text { terhadap semua warga sekolah }\end{array}$ & $\begin{array}{l}\text { Sejalan dengan Kunci Sukses Kepemimpinan Kepala Sekolah dalam } \\
\text { buku } \quad \text { Manajemen } \quad \text { Kepemimpinan } \\
\text { Kekepalasekolahan oleh Sudarwo Danim dan Suparno. }\end{array}$ \\
\hline
\end{tabular}

Dari tabel diatas, dapat disimpulkan bahwa kepala sekolah di kedua lembaga sekolah tersebut sudah menerapkan gaya kepemimpinan transformasional dalam organisasi. Hal 
Penerapan Gaya Kepemimpinan Transformasional Dalam Manajemen PAUD di Kecamatan Sidorejo Salatiga (Mei Hardika Senny, Lanny Wijayaningsih, Mozes Kurniawan)

tersebut juga diperkuat dengan hasil wawancara yang peneliti peroleh. Berikut merupakan sifat-sifat pemimpin transformasional dalam melaksanakan tugasnya sehari-hari yang peneliti peroleh:

- Pemimpin sangat menjaga hubungan baik dengan staf dan guru di sekolah, hubungan guru dengan pemimpin sudah seperti keluarga.

- Pemimpin memberikan keterangan yang jelas kepada staf dan guru serta melihat kemampuan serta latar belakang guru dalam mendelegasikan tugas.

- Pemimpin sangat terbuka pada pembaruan dalam dunia pendidikan dan selau menerima ide-ide yang diberikan bawahan selama hal tersebut tidak menyimpang dari visi dan misi sekolah.

- Pemimpin selalu memotivasi kepada bawahannya untuk meningkatkan kemampuan interpersonalnya, intelegensinya dan kepercayaan diri bawahan melalui pemberian tugas ataupun mengikutsertakan bawahan dalam diklat, pelatihan-pelatihan ataupun lomba.

- Dalam mengambil keputusan ketika terdapat suatu masalah, hal pertama yang dilakukan pemimpin adalah melihat permasalahan terlebih dahulu, jika masalah tersebut berat,pemimpin butuh waktu untuk berpikir, namun masalah tersebut tidak dibiarkan berlarut-larut,segera ditangani dengan tegas, sabar dan bermusyawarah dengan bawahan jika memungkinkan.

- Pemimpin menjadi role model untuk bawahan.

Dari hasil wawancara yang peneliti peroleh, maka peneliti membagi menjadi 4 kategori dari kepemimpinan transformasional yang peneliti temukan di lapangan yaitu yang pertama, kepala sekolah sebagai motivator, contohnya memfasilitasi bawahan agar lebih mengembangkan potensi yang dimiliki bawahan. Ke dua, kepala sekolah sebagai edukator sebagai contoh, kepala sekolah melaksanakan peran dalam membimbing peserta didik, tenaga pendidik dan kependidikan kepala sekolah memfasilitasi bawahan agar meningkatkan kemampuan interpersonalnya. Ke tiga, sebagai inovator, contohnya mampu bekerja sama dan menjalin relasi dengan semua orang dan mampu memecahkan masalah yang terjadi melalui kemampuan dan strategi yang dimilikinya. Ke empat, sebagai manajer yaitu kepala sekolah mampu menjalankan pengelolaan kurikulum, siswa, keuangan, fasilitas sekolah, administrasi, serta hubungan kedalam dan keluar sekolah. Hal tersebut diatas sesuai dengan teori milik Mulyasa (2009 : 98-122).

Beberapa kategori dan hasil observasi maupun wawancara yang penulis peroleh menjadikan sebuah kesimpulan besar bahwa kepala sekolah yang menerapkan gaya kepemimpinan transformasional dapat menerima pembaharuan dalam dunia pendidikan yang akan dipakai untuk kegiatan belajar mengajar, kepala sekolah menjadi teladan, mendorong kinerja bawahan, mengharmoniskan lingkungan kerja, memberdayakan karyawan, bertindak atas sistem nilai, meningkatkan kemampuannya terus menerus, memiliki hubungan yang hangat dengan seluruh warga sekolah dan lingkungan sekitar dan memiliki kemampuan untuk mengahdapi situasi yang rumit. Semua itu dapat dicapai oleh kepala sekolah apabila dia memiliki kemampuan berkomunikasi secara persuasif, motivasi untuk berprestasi dan pengetahuan manajerial yang mencukupi, seperti yang dikatakan oleh Danim dan Suparno (2009:77).

\section{SIMPULAN DAN SARAN}

\section{Simpulan}

Berdasarkan hasil dari analisis data dan pembahasan penelitian di atas, mengenai penerapan gaya kepemimpinan transformasional dalam manajemen PAUD, maka dapat disimpulkan sebagai berikut. Hasil penelitian membuktikan bahwa gaya kepemimpinan transformasional sudah diterapkan di beberapa sekolah di Kecamatan Sidorejo Salatiga dan 
berjalan sangat baik dan efektif. Hal ini dibuktikan dengan beberapa kepala sekolah yang ada di lembaga TK Kecamatan Sidorejo selalu memberikan motivasi inspiratif dan stimulasi intelektual kepada bawahannya, serta memberikan perhatian individual guna mengoptimalkan kelebihan pada diri bawahan masing-masing sehingga tugas yang diberikan dapat dicapai secara maksimal. Peneliti melihat beberapa hasil dari penerapan gaya kepemimpinan transformasional pada lembaga TK di Kecamatan Sidorejo yaitu: output yang dihasilkan lebih baik (misalnya, guru menjalankan profesinya dengan penuh tanggung jawab dan panggilan dari hati), hubungan seluruh warga sekolah terjalin dengan hangat dan kekeluargaan, visi misi dan tujuan sekolah dapat tercapai dan lembaga sekolah dapat berkembang).

\section{Saran}

Saran-saran yang perlu diberikan dari hasil penelitian diatas adalah sebagai berikut :

a. Bagi Kepala Sekolah: 1) Ada baiknya bahwa seorang kepala sekolah mempunyai sikap terbuka, percaya dan hubungan yang hangat dengan seluruh warga di sekolah, terutama dalam memahami kelebihan dan kekurangan masing-masing dari setiap warga sekolah agar dalam menjalankan tugas hasilnya dapat maksimal. Jika hasil yang diperoleh maksimal maka tujuan dari visi misi sekolah dapat tercapai dengan mudah, tentunya dengan pemberian motivasi dan stimulasi intelektual yang diberikan kepala sekolah. 2) Kepala sekolah diharapkan mampu untuk mengelola hubungan baik dengan siapapun baik di dalam lingkungan sekolah maupun di luar. Karena hal tersebut merupakan jati diri yang akan membuat hal positif dari pandangan masyarakat sekitar mengenai lembaga sekolah. 3) Kepala sekolah diharapkan memiliki strategi tertentu dalam menghadapi konflik, tuntutan dan pemaruan dalam dunia pendidikan. Untuk itu, diperlukan sifat yang adil, tegas, mampu mengelola emosi, disiplin, jujur, hangat dan humoris.

b. Bagi Guru: 1) Guru diharapkan dapat meningkatkan kompetensinya secara terusmenerus agar dapat menjadi guru yang berkualitas dan profesional. Hal tersebut terlebih guna menyiapkan diri untuk menghadapi perkembangan jaman, pembaruan dalam dunia pendidikan dan berbagai karakter yang ada pada dalam diri anak. 2) Guru hendaknya dalam melakukan tugasnya tidak hanya semata-mata karena seorang pendidik, akan tetapi seyogyanya dapat melakukan semua tugasnya dikarenakan oleh panggilan jiwa, bukan karena imbalan ataupun jabatan yang akan ia dapatkan. Sehingga dalam melaksanakan tugas tidak ada beban dan menyadari akan tanggung jawabnya. 3) Dalam mendidik murid-muridnya hendaknya para guru menganggap bahwa semua murid adalah anak kandungnya yang akan menggapai cita-cita setinggi-tingginya agar dalam mendidik timbul rasa tulus ikhlas dan sabar.

\section{UCAPAN TERIMAKASIH}

Puji syukur penulis panjatkan kehadirat Allah SWT karena berkat rahmat dan anugerah, dan karunia-Nya yang sangat melimpah maka skripsi ini dapat terselesaikan dengan judul Penerapan Gaya Kepemimpinan Transformasional Dalam Manajemen PAUD di Kecamatan Sidorejo Salatiga. Penulisan skripsi ini dapat berjalan dengan baik karena banyaknya dukungan dari berbagai pihak.

\section{DAFTAR PUSTAKA}

Anggayani Ni Luh, I Putu Dharmanu Yudharta, Piers Andreas Noak, 2016. Analisis Gaya Kepemimpinan Kepala Sekolah Dalam Meningkatkan Kinerja Guru (Studi Kasus Sekolah Dasar Negeri 2 Pemecutan Kota Denpasar). Citizen Charter 1(1), 1-8. 
Penerapan Gaya Kepemimpinan Transformasional Dalam Manajemen PAUD di Kecamatan Sidorejo Salatiga (Mei Hardika Senny, Lanny Wijayaningsih, Mozes Kurniawan)

Cahyadi HG, 2006. Pengaruh Gaya Kepemimpinan Terhadap Peningkatan Produktivitas Kerja Menurut Persepsi Karyawan (Studi Kasus Pada PT. Ultrajaya Milk Industri and Trading Company, Tbk.). Universitas Widyatama.

Dahono, 2014. Peran Kepala Sekolah Sebagai Supervisor, Motivator dan Inspirator Dalam Rangka Peningkatan Kinerja Mengajar. Tesis, Universitas Kristen Satya Wacana.

Danim Sudarwo dan Suparno 2009. Manajemen dan Kepemimpinan Transformasional Kekepalasekolahan. Jakarta : Rineka Cipta.

Ernawati Ita, 2011. Pengaruh Kepemimpinan Transformasional, Motivasi Kerja dan Lingkungan Kerja Terhadap Kinerja Karyawan Bagian Produksi Pada CV.Graha Indah Furniture Jepara. Skripsi, Universitas Negeri Semarang.

Hariza H, 2017. Implementasi Peran Kepala Madrasah Sebagai Manager Dalam Meningkatkan Kinerja Guru di MTs N 1 Kota Agung Kec.Kota Agung Kabupaten Tenggamus. Undergraduate thesis, UIN Raden Intan Lampung.

Hasibuan Y. Junialis 2016. Peran Kepemimpinan Transformasional Kepala Sekolah Dalam Meningkatkan Kinerja Guru (Survei Pada Yayasan Tarakanita dan Yayasan Mardiwijana Gonzaga). Skripsi, Universitas Sanata Dharma.

Historika Novanri 2012. Pengaruh Gaya Kepemimpinan dan Motivasi Kerja Terhadap Kinerja Pegawai pada Dinas Perhubungan Provinsi Kepulauan Riau. Masters thesis, Universitas Terbuka.

Kusumawati, D. 2017. Manajemen Sarana Prasarana di Day Care Baby's Home Salatiga. Scholaria: Jurnal Pendidikan Dan Kebudayaan, 7(1), 17-25.

Larasati Tika, 2012. Kualitas Hidup Pada Wanita Yang Sudah Memasuki Masa Menopause. Universitas Guna Dharma.

Lestari TP,2015. Persepsi mahasiswa akuntansi dalam pemilihan karir menjadi praktisi akuntansi syariah: Studi empiris mahasiswa akuntansi angkatan 2011 UIN Maulana Malik Ibrahim Malang. Undergraduate thesis, Universitas Islam Negeri Maulana Malik Ibrahim.

Pradana Martha Andy, Bambang Swasto Sunuharyo, Djamhur Hamid 2013. Pengaruh Gaya Kepemimpinan Transformasional dan Transaksional Terhadap Kinerja Karyawan (Studi Pada Karyawan Tetap PT. Mustika Bahana Jaya, Lumajang). Universitas Brawijaya Malang.

Rio Fetha, NN 2012. Hubungan Kepemimpinan Kepala Desa Dengan Efektivitas Kerja Perangkat Desa (Studi Pada Pemerintah Desa Talang Bojong Kecamatan Kotabumi Kota Kabupaten Lampung Utara). Karya-Karya Umum, Universitas Lampung.

Sinaga YP, 2010. Pengaruh Gaya Kepemimpinan Transformasional dan Gaya Kepemimpinan Transaksional Terhadap Produktivitas Karyawan Dengan Motivasi Sebagai Intervening Variabel (Studi Pada Karyawan CV. Cahaya Setia Mulya Yogyakarta). S1 thesis, UAJY.

Slameto S, 2014. Permasalahan-Permasalahan Terkait Dengan Profesi Guru Sd. Scholaria: Jurnal Pendidikan Dan Kebudayaan, 4(3), 1-12.

Subhan, Moh 2013. Kepemimpinan Islami Dalam Peningkatan Mutu Lembaga Pendidikan Islam. Tadris Sekolah Tinggi Agama Islam Nahdlatut Thullab Sampang, 8(1), 126135.

Sugiyono 2010. Metode Penelitian Pendidikan. Bandung : Alfabeta. 
Sulistyo Heru, 2009. Analisis Kepemimpinan Spiritual dan Komunikasi Organisasional Terhadap Kinerja Karyawan. Jurnal Fakultas Ekonomi Universitas Islam Sultan Agung Semarang.

Suwardi dan Samino 2014. Kepemimpinan Kepala Sekolah Dalam Pengembangan Lembaga Pendidikan Islam Sekolah Kreatif SD Muhammadiyah Kota Madiun. Jurnal Manajemen Pendidikan, 9(2), 186-195.

Widayanti Eka Rizki, 2016. Pengaruh Penerapan Metode Teams Games Tournament Berbantuan Permainan Dadu Terhadap Hasil Belajar IPA Kelas 3 SDN Lemahireng O2BawenSemester II Tahun Ajaran 2015/2016. Skripsi Universitas Kristen Satya Wacana.

Widhiastuti Rini, Bambang Sudjatmoko, Suyatmini 2013. Kontribusi Kepemimpinan Transformasional Kepala Sekolah, Budaya Organisasi, dan Keterampilan Guru Terhadap Kinerja Guru SD di UPT Dinas Pendidikan Kecamatan Sukorejo. Naskah Publikasi, Universitas Muhammadiyah Surakarta.

Zulaini NR, 2010. Pengaruh Pelaksanaan Pelatihan Terhadap Disiplin Kerja Karyawan Pada Yayasan Kesejahteraan Pendidikan Dan Perumahan. Skripsi Universitas Widyatama. 